\title{
Readdressing the Ethno-Religious Conflicts in Southern Kaduna, Nigeria in the Light of Abraham-Lot Narrative (Genesis 13:1-18)
}

\author{
Favour Chukwuemeka Uroko \\ http://dx.doi./org/10.4314/ujah.v19i2.2
}

\section{Abstract}

This article examines ethno-religious conflict in southern Kaduna and its negative impacts on development in the region. Several efforts have been made by the government and organisations to stop these reoccurring conflicts, however, the conflict continues to aggravate. It is the objective of this article to look at the factors encouraging this negative phenomenon, through the Abraham-Lot narrative (Gen. 13:1-18). It is really unfortunate that the conflicts in southern Kaduna, which are mainly between Muslims and Christians, have claimed thousands of lives and rendered so many homeless. Data were drawn mainly from secondary sources of information, with the adoption of the descriptive phenomenological method of research. It was discovered that fight for political and religious superiority between Muslims and Christians is the sustaining factor. As part of recommendations, adherents of religious and ethnic groups should ensure fairness in resolving any conflict situation

Key words: Southern Kaduna, Muslims and Christians, Ethnic groups, Conflict Resolution, Conflict Mediation. 


\section{Introduction}

The Nigerian society, just like any other society struggles with its own social problems. One of these problems in Nigeria is the conflict in southern Kaduna. Conflict is prone to take place under any atmosphere, as far as it is a conglomeration of living things. The Nigerian society which was built on a platform of a merging together of different regions, religions, tribes and ethnic groups, has been besieged with hatred (vocal and physical) which culminates into conflicts. In the observation of Paden (2015), these conflicts situation emanates due to the evenly divided Nigerian population of just over 180 million, between Muslims and Christians.

Religious crises in southern Kaduna came to limelight with the Zango Kataf crisis of May 1992. In May 1992, in what became known as the Zangon-Kataf crisis, there were clashes in ZangonKataf between the Hausa and the Kataf (a predominantly Christian ethnic group), initially sparked off by a dispute over the relocation of a market (Akin et al 1999). The Hausa opposed the relocation of the market to the new spacious area, preferring it remained in the cramped town of Zango Kataf (Lukat, 2016). Riots erupted with the burning of churches and mosques, hospitals and educational centres. This conflict divided Kaduna state along religious lines. There became distrust in the state amongst various religious adherents. There arose what became known as Muslim and Christian neighbourhoods in Kaduna. These conflicts have continued to reoccur and hundreds of lives have been lost and are still being lost to the southern Kaduna religious crises.

According to Imo (2008), in the year 2000, Kaduna State was also debating bringing in Sharia, making local Christians extremely nervous about how this would affect them. Pastors held 
opposition meetings and published pamphlets explaining how Sharia was a target against Christians. On the contrary, Muslims held demonstrations in support of the measure. On 21st February 2000 these meetings and demonstrations were countered by a march on Government House to put forward the Christian perspective. It is unclear whether what happened next was planned or spontaneous (Harris, 2013:191). Human Rights Watch in 2013 reports that there were thousands of refugees and over 5000 people lost their lives. Furthermore, there were conflicts in 2002, and 2011. The state and the federal government have made several interventions, but none has yielded the needed effects. It is in this light that the Abraham-Lot narrative was used as lenses towards a better understanding of conflicts and better ways of resolving conflicts.

This article focuses on the impacts of the ethno-religious conflicts of southern Kaduna, Nigeria. The government has tried its best in curbing these conflicts, unfortunately, it has continued to persist. In a bid to offer a viable platform towards ameliorating the problem, the Abraham Lot narrative offers insight into effective conflict resolution. The descriptive phenomenological method of qualitative research was utilized as the research methodology, with data collected mainly from secondary sources. This methodology was used because of the fact that it produces an account of lived experience in its own terms rather than one prescribed by preexisting theoretical preconceptions (Smith and Osborn, 2015).

\section{Conceptual Explanation}

Religious conflict results when a group of people with a belief or dogma finds it difficult to accommodate the belief and dogma of another group of people. This often results in physical and vocal assaults or cold war. Religious conflicts are a more complex 
phenomenon that engages a combination of contested domains, including power, personality, space or place, and group identity (Wendy, 2017). This portends that when two religious groups struggle for supremacy in power or to show their affinity in terms of their religious beliefs, religious conflicts occur. Religious conflict is a "struggle between and among individuals or groups over values and claims to scarce resources, status symbols, and power bases. The objective of the individuals or groups during conflict is to neutralize, injure or eliminate their rivals so that they can enjoy the scarce resources, the status symbols, and power bases" (Okai, 2017, p. 22)

In Nigeria, especially in northern Nigeria, religious conflicts was firmly rooted as a response to the colonial pattern of government employed and actualized by the Lord Lugard and his men. Gofwen notes: "To convince the Northern emirs and the sultan of the commitment of the colonial government towards maintaining the socio-political status quo, it became a matter of colonial policy not to interfere with the functioning of the existing institutions, rather, they were strengthened on the condition that they were accountable and made subservient to the colonial government"(2004, p.59). Nwaomah opines that:

In these circumstances, and depending on the degree of threat that the colonial government thought each religion posed to the colonial system in a locality, the colonial authorities evolved administrative patterns that served their purpose of strengthening the colonial system. However, it seems, by its policies, that the colonial system developed a system of non-interference on Islamic affairs and seemed to have inadvertently limited the spread of Christianity in Northern Nigeria. Certain policies seemed to point in this direction. (2011, p.97) 
Hence, religious conflicts, bigotry, tension have its roots in the process of struggle for political or ideological supremacy amongst the two major religions in southern Kaduna.

National development according to Bhawna (2016) is "a process of reconstruction and development in various dimensions of a nation and development of individuals. It includes full-growth and expansion of industries, agriculture, education social, religious and cultural institutions". For Tolu Lawal and Abe Oluwatoyin (2011, p.238) national development is the "the overall development or a collective socio-economic, political as well as religious advancement of a country or nation." Religious conflicts have a lot of ce from the Britain in 1960contribution to the development of any community. When there is peace, infrastructural and intellectual development continues to be the order of the day. But, when there is war, rancour, and strive, it halts developmental plans. Furthermore, national development encompasses the transformation of community into socially, economically, politically, educationally, orderly, and materially desirable conditions (OyeAdeniyi, 2014, p. 52).

\section{The Southern Kaduna Crises}

Kauru, Kachia, Zango-Kataf, Kaura, Kagarko, Jaba, Jema'a, Sanga, are the local government areas that constitute southern Kaduna. It was known as southern Zaria before Nigeria got her independence from Britain in 1960. Most crises in southern Kaduna starts with land disputes before it degenerates into a fullblown religious war.1987 burning down of College of Education Kafanchan signalled the hatred between the Christians and Muslims in Kaduna. Zwahu Bonnat puts that Muslim Students Society attacked students of the College of Education hence the escalation of the crisis along religious lines. Ajunwa (2011) reports 
that the crisis at the college of education "spread to other parts of the state leading to the burning of places of worship, with many lives and properties worth millions of naira lost. Consequently, in 1992, the Zango Kataf Crisis catalysed the hike in killings in southern Kaduna. The Zangon Katab has the Atyap as the dominant ethnic group. The Zango Kataf crisis was bloody on February 6th and May 15th and 16th 1992.

Furthermore, in 1999, there was an ethno-religious assault and aggression against Southern Kaduna Christians. Edwards Johns (2011) reveals that residents of Jama'a emirate took the opportunity of the appointment of a new Emir of Jama'a to protest not only this appointment but the entire emirate system but unknown to them the protest turned into rioting between the Hausa minority and the non-Hausa majority resulting in the deaths of perhaps 30 persons and the injury of several others. Also, Zwahu (2012) explains that Southern Kaduna people were killed, beaten, matcheted, and Human Right Watch describes it as the single worst outbreak of violence in Nigeria since the 1967-70 civil war. Consequently, according to the Report of the Judicial Commission of Inquiry into Kaduna State Religious Disturbances of February 2000 ,

The 2000 violence in Kaduna took place in two main waves - sometimes referred to as "Sharia 1" and "Sharia 2" - a first wave from February 21 to 25, with further killings in March, followed by a second wave from May 22 to 23. In reaction to the prospect of the introduction of Sharia into Kaduna Sate (sic), the Kaduna branch of the Christian Association of Nigeria (CAN) organized a public protest on February 21. Then the situation degenerated: Muslim youths clashed with the Christian protestors, and fighting between Christians and Muslims 
spiraled (sic) out of control, with massive violence and destruction on both sides. An accurate, total death toll has never been ascertained, and as is typical in these situations, government and police officials were keen to play down the figures. A judicial commission of inquiry set up by the Kaduna state government reported that at least 1,295 people had been killed, while an unspecified additional number were buried unidentified, and others were declared missing.

Also, in 2002, in Birnin Gwari, a woman was killed, and they alleged that the killer was wearing a fez cap; one Kataf man who had been away at Zaria when the incident occurred, returned to Birnin Gwar and was killed, several other "Katafs" i.e Southern Kaduna people were killed, their houses and property burnt (Zwahu, 2012). This 2002 crisis according to international observers like the human right watch erupted because the factors that led to the 2000 crisis were not addressed.

In 2011, September 2, Zwahu explains that, a Sallah procession was allowed to take place under heavy police and military guard, and the celebrants-in-procession carried and waved different weapons, including machetes, knives, swords, cutlasses and other dangerous instruments of war and they drove their motorcycles wildly, knocked down and killed two Arna women. The youths put up strategies to defend their community but late in the evening of that day, the army JTF launched attacks on houses at Adauwan breaking down doors, dragging out youths, hammered them with gun butts, beat and brutalized them.

Very importantly to state, is the 2016 southern Kaduna massacre which some nongovernmental organizations have titled genocide against southern Kaduna indigenes. Uche (2016) narrates that the Catholic Archdiocese of Kafanchan has said the unrest in 
Southern Kaduna State has claimed 808 lives. Fifty-three villages have so far been attacked and 57 people injured, the church said. However, the Miyetti Allah Cattle Breeders Association, the umbrella organization of herdsmen notes that the group said it has lost no fewer than 6,000 cows to the crisis in Southern Kaduna. The group faulted claims by independent bodies that the indigenes of southern Kaduna were the sole victims of the conflict going on there.

\section{Causes of the Crises}

The causes of the crises in southern Kaduna cannot be underestimated. One of the causes is the fight for supremacy over land. Luka (2017) discovers from the revelation given by Musa Kaptain Solomon, president of Southern Kaduna Peoples Union, that the quest for Southern Kaduna land, through the creation of grazing reserves is the cause of the Southern Kaduna crisis. It could be deciphered that southern Kaduna has agriculture as the mainstay of her economy, hence, the vegetative nature of her ecosystem. The herdsmen having no green vegetation to use to feed their cattle resort to taking their cattle into the farm lands of the indigenes or southern Kaduna. Consequently, fully armed as the herdsmen were any resistance from the indigenes would be met with a return of fire from the nozzle of a gun and the edge of a cutlass.

Furthermore, Luka (2017) explains that the first is expropriating lands belonging to indigenes of southern Kaduna and giving it to the Fulani. The second is that if they resist, they would be killed and chased out. The third is that southern Kaduna shall be kept under perpetual intimidation until they run away from their lands on our own. Foreigners from mostly Niger, Mali and Chad have constituted themselves as tools to be used in the destruction 
of lands and properties in southern Kaduna. This is evident in the speech by the governor of Kaduna state, Mallam Rufai that the attackers were from Niger, Cameroon, Chad, Mali and Senegal and that the attack in southern Kaduna was a reprisal attack to what southern Kaduna indigenes did to them after the 2011 elections. Sola (2016) reveals that the governor further noted how he went and pleaded for a stoppage to the incessant riots in southern Kaduna the herdsmen asked for monetary compensation and he paid them. For this statement, the governor has been able to prove that the perpetrators of these crises in southern Kaduna are mercenaries from neighbouring countries.

Hate Speeches, claims and counterclaims are other contributory factors to the survival of religious conflicts in southern Kaduna. The exchange of war provoking statements from both the leaders of the Christian Association of Nigeria and the Islam leaders have fuelled the reoccurrence of the war and cold war in southern Kaduna. For the Islam leaders, Luka (2012) puts that, they said that the issue of grazing reserves is not related to this problem, because the grazing reserves have been there back to colonial days hence the right of the Fulani's to own the land, that's why they herdsmen should not be held accountable for what they do. Also, the Minister of Interior, Abdulrahman Dambazau, said: ". . there are people who are always looking for ways to further create division along religious or ethnic fault lines for their selfish interest, with the aim of creating instability in our internal security. . .. True religious leaders do not fan the embers of hate, but ensure that communities live in peace and harmony". Dambazau was referring to leaders of the CAN and the Roman Catholic church. The Kaduna state Christian Association of Nigeria replied him, "Shut up if you have nothing to say. . . it would be an unfortunate thing for a Minister like Dambazau to say that the Christian leadership in the country was 
fanning the embers of hatred.'This exchange of vocal war words has served to fuel the disputes between indigenes and non-indigenes in southern Kaduna which have degenerated into a religious conflict.

The hypocrisy of Security agencies has not helped matters, in the worsening situations in southern Kaduna. According to the report of the International Centre for investigative Justice, the killings in Southern Kaduna continue relentlessly, as the state and security agencies appear helpless in tackling the crisis and ICIJ reveals that Southern Kaduna has been attacked about 41 times between 2009 and May 1, 2016, with hundreds of deaths and thousands of property destroyed. These security agencies of Nigeria are made up of the Nigerian army, Nigerian police, and State Security Service, amongst others.

\section{Implication of the Crises to National Development}

National development could be seen as the disposal with which a state is able to cater for the lives of her citizenry. National development could be political, religious, economic or social in structure. Southern Kaduna has for long being retarded from achieving her great potentials and thus contributing her quota to the national growth and development. The survival and sponsorship of these killings of both of Christians and Muslims have not yielded any gains to both sides. Consequently, the effects that this wanton destruction of lives and properties had brought to people of southern Kaduna are innumerable.

Many hectares of Farmlands, as well as its products, have been destroyed. Food produced such as yam and tomatoes were devastated as a result of the crises. The means of livelihood of the indigenes of southern Kaduna has been destroyed. These problems have not gone down well with the people of southern Kaduna. Hungry and starvation have been the place of survivors in southern 
Kaduna. .Other implications of the ethno-religious crises in southern Kaduna are:

First, the term Internally Displaced Persons otherwise known as IDPs refers to persons or groups of persons who have been forced to flee their homes, as a result of armed conflict, situations of generalized violence, violations of human rights or natural or human made disasters, and who have not crossed an internationally recognized State border (United Nations). In Jema'a local government area alone, there are over 2234, 0000 IDPs currently. There are growing reports of food shortages in IDPs camps because these food items were stolen. Consequently, children are being smuggled and trafficked outside of the camp.

Second, the crises have led to unemployment. According to the International Labour Organization unemployment means a when a person is "without work", that means he/ she was not in paid employment or self-employment during a particular reference period; "currently available for work", that means he/she was ready for a paid employment or self-employment during the reference period; "seeking work", that means he/she had taken specific steps in a specified recent period to seek paid employment or self-employment." This is the situation in southern Kaduna currently. During the crises, so many shops and business centres were burnt to ashes. Many farm lands were destroyed.

Third, there has been a disruption of Education Programme. Formal and informal education has been disrupted since the beginning of the crises. Centers for academic learning especially primary and secondary schools were destroyed. For instance, Luka Binniyat reports that five students of the College of Education, Gidan Waya, Jema'a Local Government Area, Kaduna State, were, Sunday evening, reportedly shot dead close to Gidan Waya, when a commercial car taking them to school from Kafanchan was 
waylaid by herdsmen. The effects that this wanton destruction of lives and properties has caused to the people of Southern Kaduna cannot be overemphasized. Many deaths have been recorded which has led to the downsizing of the population. Most elderly persons, as well as children, were killed. Hence, the ideas which the young ones would have gotten from the older once have been wiped cut short, hence, there is bound to be knowledge drain, especially with the deaths of teachers and tutors.

\section{Abraham-Lot Narrative (Genesis 13:1-18) \\ a. Remote Context}

The book of Genesis 13:1-18 explains the story of Abraham and Lot. Henry ( 2006, p.95) explains that when God called Abraham he was in Ur of the Chaldees, he journeyed with his father Terah, Lot his brother's son, and Sarah his wife and travelled east to the city of Haran. Abraham's father, died in Haran. God had told Abraham to leave his father's house. Abraham had so many cattle; when he left Haran he took his wife and Lot, and all his animals which he had at Haran.

\section{b. Immediate Context}

Due to the fact that Abraham and Lot had so many possessions, animate and inanimate, their servants began to quarrel amongst themselves and this conflict was about escalating to another degree, before Abraham called his brother Lot, for both of them to have a peace deal. Alan (2003), sketches that both Abram and Lot had gained immense wealth and power, and their problem remained unresolved and eventually developed into a bone of contention. This is because each of them wanted the best grazing ground for their flocks and herds. 
According to Genesis 13:6, Abraham and Lot had conflict because they both had many animals with not much grass to feed them. It reads: And so there was not enough pasture land for the two of them to stay together, because they had too many animals $(N I V)$. This pasture was the available resource that was available. The Hebrew word used for pasture was הָָָר (ha.'a.retz) which means earth or land. This shows that the struggle for land was the cause of the feud between Abraham and Lot. In Nigeria, fight over the available resources such as land, petroleum, allocation and derivations from the federal government, among others have continued to be a motivating factor to conflicts in Nigeria.

From Verses 8-9, it was discovered that Abraham took the role of a conflict mediator and reconciliatory stand, by stating,

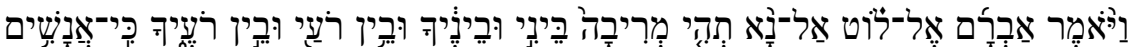

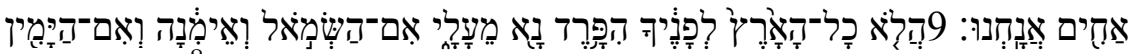

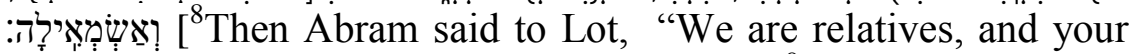
men and my men shouldn't be quarrelling.' So let's separate. Choose any part of the land you want. You go one way, and I will go the other (NIV)]. Gill (1999) exemplifies that Abraham in order to make peace, he makes the proposal first, and lays a scheme before Lot for their future friendship. In relation to Nigeria, lack of a conflict mediator, and lack of honesty among the various religions have continued to escalate religious and ethnic conflicts in Nigeria.

\section{Recommendations}

The following recommendations are hereunder made:

1. One among the Religious groups or ethnic groups as the case may be should serve as a mediator, towards making sure that the conflict between his religion or ethnic group and others does not escalate. This the mediator could do by calling the 
leader of the other group and finding the remote and immediate causative factors of that conflict situation. This was the role of Abraham in his bid to resolve the conflict between his group and those of Lot.

2. Adherents of religious and ethnic groups should ensure fairness in resolving any conflict situation. Religious groups should be able to give up their interest, just for peace to reign. Selfishness must be avoided, and equalitarianism embraced. Abraham was able to ensure fairness during the resolution of Lot conflicting interest to his. He allocated the best of resources to the other group, that of Lot so that peace would reign.

3. Furthermore, after Abraham was able to mediate and resolve his feud with Lot, it was not recorded that Abraham went against the agreement, neither was it recorded that he trespass his boundary. Thus, this is a clarion call the adherents of the various religious groups not to intrude into lands or forcefully try to possessed property that belongs to other religious or ethnic groups. Olubomehin $(2012$, p.145) theorize that "the last stage of the conflict resolution was the signing of a peace pact". This peace pact must be adhered to

4. Also, this paper serves as a clarion call to the minister and his team in the ministry of interior, to utilize the local government machinery as a sure way towards dealing with conflicts (be it religious or communal), rather than paying lip service on the pages of newspapers. Chairmen of local governments in southern Kaduna, have a good knowledge of any conflict situation in their locality, thus the ministry of interior should utilize them.

5. The Nigerian media should avoid giving a very extreme and very exceeding picture of religious or ethnic clashes. 
Inflammatory statements and unguarded utterances should be avoided. They should report the issue just the way they see it. This was the method of Abraham. He never told his followers that Lot took the better part of the land when compared to his. He gave a report that facilitated the peace process which he initiated.

\section{Conclusion}

The southern Kaduna crises are driven by religion and ethnicity. These reoccurring conflicts have led to the sad state of southern Kaduna -economically, politically and culturally. Many lives and property have been destroyed as a result of the religious conflicts between Christians and Muslims in southern Kaduna. The December 2016 Massacre of defenceless women, children and the elderly men in southern Kaduna demand condemnation from spirited individuals and the government. Dialogue should be used as a way of settling disputes rather than resorting to violence. The government should make sure that all those involved in any act of religious conflicts should be made to bear the full weight of the law.

\section{Favour Chukwuemeka Uroko}

Department of Religion and

Cultural Studies

University of Nigeria, Nsukka 


\section{References}

Ajunwa, Patrick. (2011). "Genesis of Religious and Ethnic Crisis in Northern Nigeria". Nigeriancommentaries blog, 6 March 2011. Web 12 March 2017.

Akin Akinteye, James Wuye, and Muhammad Ashafa. (1999). "Zangon Kataf crisis: a case study," in Community conflicts in Nigeria: management, resolution and transformation, Onigu Otite and Isaac Olawale Albert (eds.). Ibadan: Academic Associates Peaceworks.

Alan, Carr. (2003). Abraham: Following In the Footsteps of Faith. Retrieved from http://www. Sermonnotebook. org/ old\%20testament/Gen\%2013_5-13.htm.

Bhawna, Bawa. (2016). National Development: Meaning and Problems. Web. 7 January 2016. http://www.yourarticlelibrary.com/society/nationaldevelopment-meaning-and-problems/76824/.

Colette Harris (2013) Violence in a Religiously Divided City: Kaduna, Nigeria-From the Shari'a Riots of 2000 to the Post-election Clashes of 2011, Space and Polity, 17:3, 284299.

Edwards, Johns. (2000). "Domestic Aliens: The Zangon Kataf Crisis and the African Concept of "Stranger." International Research Group for Transregional \& Emerging Area Studies. Accessed June 13, 2017. Http://iteas.net/domestic-aliens-the-zangon-kataf-crisisand-the-african-concept-of-stranger/.

Elanza News. (2017). "Profitable Natural Resources, Nickel found in Southern Kaduna." Accessed on 12 July, 2017, http://www.elanzanews.com/profitable-natural-resourcesnickel-found-in-southern-kaduna/ 
Gill, John. (1999). "Commentary on Genesis 13:8". The New John Gill Exposition of the Entire Bible. Retrieved from http://www.studylight.org/commentaries/geb/genesis13.html.

Gofwen, Rotgak. (2004). Religious Conflicts in Northern Nigeria and Nation Building: The Throes of two Decades 19802000. Kaduna: Human Rights Monitor (HRM).

Henry, Halley. (2006). Halley's Bible Handbook. Grand Rapids: Zondervan Pub. House.

Human Rights Watch (HRW) (2003) The "Miss World Riots": Continued Impunity for Killings in Kaduna, Human Rights Watch, 15(13)(A). Available at http://www.hrw.org /reports /2003/07/22/ miss-world-riots.

IMO, C. (2008) Evangelicals, Muslims, and Democracy: With Particular Reference to the Declaration of Sharia in Northern Nigeria, in: T. O. RANGER (Ed.) Evangelical Christianity and Democracy in Africa, pp. 37-66. Oxford: Oxford University Press

JSmith \& Mike, Osborn. "Interpretative phenomenological analysis as a useful Methodology for Research on the lived experience of Pain." British Journal of Pain, 9.1 (2015): 41-42.

Luka Binniyat.(2016). "Inside Zango-Kataf chiefdom, 24 years after killings in natives' battle with Hausa-Fulani settlers." https://www.vanguardngr.com/2016/11/inside-zango-katafchiefdom-24-years-killings-natives-battle-hausa-fulanisettlers/

Luka, Binniyat. (2017) "Southern Kaduna crisis making sense claims counterclaims." Vanguard Newspaper, 15 JANUARY 2017. Web. 12 June 2017. 
Nwaomah, S. M. (2011). "Religious Crises in Nigeria:

Manifestation, Effect and the Way Forward". Journal of

Sociology, Psychology and Anthropology in Practice, 3.2,

94-104.

Okai, M. O. (2007).“The Role of the Christian Church in Conflict

Management in the Niger Delta Region of Nigeria". An

Unpublished Ph.D Thesis submitted to the Graduate School, University of Calabar, Calabar.

Olubomehin O. Oladipo (2012). "Ethnic and Communal Clashes in

Nigeria: The Case of the Sagamu 1999 Hausa-Yoruba

Conflict". African Research Review. An International

Multidisciplinary Journal, Ethiopia, 6 (3).

OyeAdeniyi, Joseph.(2014). "National Development Strategies:

Challenges and Options", International Journal of Humanities and Social Science Invention, 3.4,51-58

Paden, John. (2015). "Religion and Conflict in Nigeria Countdown to the 2015 Elections". United States Institute of Peace. Retrieved from

https://www.usip.org/sites/default/files/SR359-Religionand-Conflict-in-Nigeria.pdf

Smith, J., and Osborn, M. (2015). "Interpretative Phenomenological Analysis as a useful methodology for research on the lived experience of pain". British Journal of Pain 9.1 (2015): 41-42.

Sola, Ojo. (2016). "El-Rufai under fire over comment on southern Kaduna killings." Daily Sun, 8th December 2016.Web. 5 August 2017.

Tolu, Lawal, Abe, Oluwatoyin. (2011). "National development in

Nigeria: Issues, challenges and prospects." Journal of Public Administration and Policy Research, 3.9:237-241. 
Uche, Atuma. (2016). "Church says '808 killed in Southern Kaduna.” Daily Sun, 30 December 2016. Web. 12 May 2017.

Wendy, Mayer. (2017). Religious Conflict: Definitions, Problems and Theoretical Approaches. Accessed on 12th March 2017 , https://www.academia.edu/5701344/Religious_conflict_De finitions_problems_and_theoretical_approaches

Zwahu Bonnat.(2012). "Contemporary ethnic and religious crises in Kaduna State." Vanguard Newspaper, 24 JUNE 2012. Web. 7 February 2016. 